price and the provision of cod liver oil and fruit juice have raised the general level of the diet of pregnant women above the average which existed before the War. Diets are now more uniform. A survey of the nutritional status and health of pregnant women now should give useful information on their reactions to standard conditions, and a comparison with pre-war records would indicate the effects of certain changes in diet.

We need to know more about the physiology of pregnancy. Why is it that a woman appears to need extra supplies of vitamins $A, B_{1}$ and $C$ during pregnancy? What is the purpose of the extra store of protein that is accumulated by a pregnant animal ? Why, as Dr. T. Moore pointed out, has a baby, at birth, such a low stock of vitamin A ? When we can answer these questions, we shall be in a better position to know what clinical evidences of deficiency we should look for and to lay down the food requirements of pregnancy. Prof. Huggett gave personal estimates of the levels to which the diet of a pregnant woman should be raised : 1-1.5 gm. of protein per $\mathrm{kgm}$. of body weight, $1-1.5$ of calcium and phosphorus, increased amounts of vitamins, particularly $A, B_{1}$ and $D$; supplements of iron; in terms of actual food-stuffs, more cheese, milk, vegetables and fruit. Until we have better knowledge of the physiology of pregnancy and more detailed evidence of the effects of diet on the health of mother and baby, we cannot assess the relative urgency of these demands. But pregnant women form such a small fraction of the total population and their health is of such importance, that they should, for the present, be given the benefit of any doubt and be allowed a prior claim gn our food supply.

\section{TRAWLING AND THE STOCKS OF FISH}

$\mathrm{I}^{\mathrm{N}}$ $\mathrm{N}$ a paper read before the Royal Society of Arts on January 27 on "Trawling and the Stocks of Fish", Dr. E. S. Russell, director of fishery investigations, Ministry of Agriculture and Fisheries, brought out in a convincing manner the problems which will confront us after the War in connexion with the national fish stocks of Great Britain and those of our near neighbours. In a summary of the history of the trawling industry from its beginning rather more than a century ago up to the present day, he traced its gradual growth. The demersal fishery, consisting of those fish living on or near the bottom, such as cod, haddock, hake, plaice and others, began with sailing boats fishing near shore. Then they ventured into the deep waters of the North Sea and, with the advent of the steam trawler and the great spread of fishing, went as far as Iceland and the Faroes, the Barents Sea and Bear Island, south of Spitsbergen. It is a tale of ever-increasing strength in boats and gear, and, running with it, an increase of fish-up to a certain point.

In 1866, a Royal Commission recommended that all restrictions on deep-sea fishing should be swept away and the industry allowed complete freedom of development-a measure which favoured enormously the later expansion of the trawl fisheries. It is a different matter nowadays. During the period of expansion there has been an almost continuous increase in the size and power of the steam trawler and in its fishing quality. It is a case of continued exploitation of the stocks of fish, beginning in a small way on grounds nearest at hand and spreading to all waters within reach, made possible by technical improvements in ships and gear and the building up of the fishing fleets in ever-growing strength.

The stocks of fish are not unlimited. The intense fishing made inroads into these stocks which are shown in the detailed statistics available, some of which were quoted by Dr. Russell. Those from the beginning of the century show a marked increase in the quantity of fish landed from 1886 to 1907 ; then follows a period of stabilization. With less fishing, landings necessarily fell heavily in the war period during 1914-18, in 1919-20 recovered to a level rather higher than pre-war, and in 1928 were not very different from 1907-13. Then comes a time when there is a sign of over-fishing. The landings fall off notwithstanding improvements in gear, and the average size of the fish is less. In spite of the fact that the war years had made it possible for the fish to recuperate, the very intense fishing which came after had made inroads on the stocks which could not be balanced. The only exception to the diminution of the stock was the cod in the extreme north. Here the fish were so unusually abundant, owing to changed hydrographical conditions, that this fishery itself was obliged to exercise restriction. Apart from the cod, the density of all the important demersal fish was steadily diminishing. Over-fishing was clearly the cause. The fish were not allowed to grow up.

At this point the present War broke out: once again, far fewer vessels are engaged in the fishery, once again the fish have recuperated and have grown to their full size and strength. After the War of 1914-18, enough was not known of the causes of these diminishing stocks. Modern research gives us no such excuse. As Dr. Russell states: "A conclusion of great importance has been reached, namely, that in most fully developed fisheries a state of over-fishing has been reached, a state where the ever-increasing intensity of fishing has resulted, not in an augmentation of the catch but in a diminution". He illustrates this by the haddock statistics, but it is the same story with almost any of the other important demersal fish. He has dealt with the subject fully in his recent book, "The Over-Fishing Problem" (Cambridge, 1942).

There is a grave warning here. Already something has been done by enlarging the mesh of the nets in order that immature fish may escape, but the question of immature fish, important as it is, is not nearly so important as the question of over-fishing. Canada has already so successfully controlled her halibut fishery that it has improved enormously.

With recuperated stocks and fishing fleets greatly reduced by the ravages of war, there are now exceptional opportunities to plan a more rational exploita. tion of the fisheries of Great Britain, and for this it is evident that international agreement will be needed. The object of such agreement will be to secure from each fishery area the maximum steady yield that the stocks can afford-to draw the interest while leaving the capital untouched. The only cure for over-fishing is to fish less, but with our improved knowledge it is clear that proper control will bring better profit to the industry and will lead to an increase, rather than a decrease, in the amount of fish landed. 